\title{
Research on the Teaching of Elite Education for College Students
}

\author{
Zeng Rui \\ College of Field Engineering \\ PLA Univ. of Sci. \& Tech \\ Nanjing, 210007, China \\ E-mail:zri1980@126.com
}

\author{
Zeng Rui, Zhang Yong, Sun Jinkun, Li Qinhui \\ Department of Airfield Engineering \&Military Supplies \\ Xu zhou Air Force Logistics College \\ Xuzhou, 221000, China \\ E-mail:79450724@qq.com
}

\begin{abstract}
This paper expounds the necessity of promoting the elite education from three aspects: the need of the development of the University, the need of the development of the country and the need of individual development. Around the advantage of small class interactive teaching, including content and principles, the teaching method of elite education in small class has been deeply analyzed and studied. Small class teaching is a better way to implement the concept of elite education at present. Compared to the class teaching, small class teaching can create more for college students to participate in seminars, interactive exchange opportunities, so as to promote the full development of students' personality. In order to eliminate the concept of higher education, management and funding of the misunderstanding, the local colleges and universities in the elite education in the exploration of the experience of thinking and alert in the end of this paper.
\end{abstract}

Keywords_elite education;college student;small class teaching; University; higher education

\section{INTRODUCTION}

"Elite education", as its name implies, is a kind of education for the elite. Traditional elite education embodies a kind of "quantity" of education, which few people enjoy are not elite education in the true sense[1]. In contrast, elite education in Higher Education is under the shows of "quality" education. Especially excellent education which is flat on the table of high level education in the mass is a high standard of education to human mind and personality as the core is built on the basis of profound knowledge. Under the background of higher education, if we can't reach the quality requirements, even if the number of higher education is little, it can't be called the elite education[2]. The last century at the end of 90s, Professor Martin Tero of the United States from the personnel training quality dimension described the elite to change mass higher education issues, he believed that the main function of the "elite education" was the education and training through strict selection of students, to enable them to meet the needs of high standard and highly creative intellectual work". The "elite education" has double meanings in theory and practice. First, it is the education stage in the process of higher education development, and the second is the talent training mode for the purpose of cultivating the social elite[3,4]. With the development of higher education, elite education extension is expanding, constantly enrich the connotation in the elite education. Elite education and higher education stage education popularization stage has be quite different ideas and orientations in education[5,6]. The implementation of the "elite education" in university education, we must innovate the teaching process and training mode, further highlight the scientific method, scientific thinking, scientific practice, pay attention to give students more space for thinking and so on, all of these have become a new research topic in front of us.

\section{The NECESSITY OF PROMOtING THE "Elite EDUCATION" IN UNIVERSITIES}

Elite is the core of elite education. Elites can be divided into different elites according to different fields and different purposes. In general education is the leading elite training leaders in politics, with professional education as the leading elite training senior management of all kinds of social organizations. Newman said in the "ideal university": "a college is a collection of heroes hall. Students around the world come here to seek the world all kinds of knowledge." Mr. Cai Yuanpei, in his speech to the president of Peking University, said: "the University is the study of profound knowledge." Elite education is related to the long-term construction and development of University, which will have a significant impact on the structure and mode of university education in the future. Therefore, it is necessary to promote the "elite education" in the University, mainly in the following three aspects:

\section{A. University's own development needs the elite education}

The national strength of the competition in the final analysis is the national talent competition, and the demand for talent of the elite countries is even more prominent. The elite education, as the top of the higher education, is the main way to cultivate the elite talents, and is an important part of the university teaching innovation system. The University of elite education in the process of cultivation of university needs innovative talents and outstanding talents, charged with any other organization. The elite education is not only a kind of return to the traditional concept of university education. It is the internal logic of the innovation of higher education concept of university. The new era calls for university training mode and elite education is the breakthrough and innovation of training mode of a powerful starting point. Therefore, the elite education is the need of the development of the university itself, and it will not disappear with the popularization of higher education in the country. 


\section{B. The development of the country needs the elite education}

The elite talent has a very important role in the development of the country. Today's era is the era of knowledge economy and the information age. The university must develop the top of the elite talents to enhance the country's comprehensive national strength, and promote the modernization of the country, so that its continuous development and growth. Therefore, through higher education makes the students' scientific and cultural quality has reached a certain level of one hand, on the other hand we need through the elite education to cultivate talents of high level talents and professional comprehensive ability, outstanding talent and have higher innovation ability. The University of university students in the knowledge structure and ability of practice, and failed to fully comply with the basic requirements of national counterparts, and quite a part of students' specialty advantage is not obvious. The lack of development potential, this is due to the lack of formal university effectively caused by the "elite education" in a certain extent.

\section{The development of College Students' individual needs elite education}

College students as an educated, life experience, hobbies, personality, intelligence, ability and the pursuit of goals and other aspects are different, so that their expectations for education are also different. Therefore, we should not only meet the needs of the development of higher education, but also to meet the needs of a part of the development of the elite education. Only in this way can we respect each student's individuality, and make each person's talent and potential to be the best.

\section{The Small Class Teaching Method of "Elite EDUCATION" IN THE UNIVERSITY}

For small class teaching, interactive teaching method is an important means of teaching in small classes, which means in the teaching of both teaching and learning of communication and negotiation, the method based on equal to each other, listen to each other, and accept one another openly, even persuade through rational debate, stimulate the initiative of both teachers and students, so as to improve the development of creative thinking, a teaching method of teaching effect. Application of interactive teaching method more widely and more flexible is an important difference between the bottom and top class teaching.

\section{A. Advantages of small class interactive teaching}

Interactive teaching in small classes under the conditions established in the "generativism" teaching view, which is not only to impart knowledge, even lead to obtain knowledge and skills to guide students autonomous learning, help students understand the constantly changing environment and maximize their potential. The students actively construct change from passive knowledge receivers for the meaning of life. Due to the changes of various conditions are relatively large, interactive class condition has the following advantages:
1) The number of "less" is more likely to play a double active role

A large class asks the students not to speak, and abide by the order of the class. Small class makes, university teachers and students have more two-way communication opportunity, or dispel misunderstanding, so as to realize students challenge teachers and teachers to activate the students.

2) "Big" space is more likely to reflect the double dominant effect

In the small class, interactive teaching can fully mobilize students' enthusiasm, initiative and creativity, teachers' authority, mode of thinking, practical problem solving ability is challenged, and the dominant position of teachers and students in the classroom is switched from time to time. A student's main problem may become the main tone of the classroom teaching.

3) Time "live" is more likely to improve the ability of double innovation

The traditional teaching is only on the theoretical knowledge of the book block coding. This is a kind of creative work, but its teaching effect is limited. University students' thinking ability, knowledge and information in some ways are even more than teachers and teachers simultaneously, through the interaction between teachers and students in class teaching.

4) Position "change" is more likely to promote the level of double effect

Traditional teaching only stresses teachers' influence on students, while ignoring the role of students. Interactive teaching is the teaching of the two sides to coordinate democracy and equality. In the small class, the students and the university teachers have to adjust the position of university teachers to leave students more convenient, by changing the teaching position, change the angle of the information transfer and other ways to arouse students' interest.

\section{B. The contents of small class interactive teaching}

The method is for the purpose of service, whether it is large or small, no matter what method, the ultimate aim is to achieve the purpose of teaching, meet the students' needs. Interactive teaching as a new way to adapt to the characteristics of students' psychological, in accordance with the trend of the times, but also in the practice of continuous development. Teaching has a law, but no fixed method. Generally speaking, there are many effective methods and steps in the interaction of small class, and the contents are more abundant and flexible.

\section{1) The teaching of basic theoretical knowledge}

Turning to the teaching of basic theoretical knowledge, I am afraid it will make people doubt whether this is a teaching type. In fact, the use of any kind of teaching mode is not a personal independence of conduct will intervene, with other teaching mode more or less. The key to the problem lies in the promotion and implementation of the interactive teaching method in small class. Although the basic theoretical knowledge of teaching can also be achieved in the teaching of interaction, but in addition to the basic knowledge of the key difficult points can be interactive, the other basic knowledge 
of the teaching should not be used. Otherwise there will be contrary to the overall objective of teaching interaction, classroom teaching will occupy more time.

\section{2) Appropriate interactive topics}

The interactive topic mainly depends on whether the topic can realize the purpose of interactive teaching. General shall comply with the following conditions: the topic should be the ability to accept students should fully consider the topic; the whole teaching process of discipline from easy to difficult topics for debate; and enlightening and thinking of the topic; should be able to fully mobilize the enthusiasm of the students; the topic should be close to or near the textbooks to solve practical problems original.

\section{3) Reasonable comment}

When the students have their own views and opinions put forward according to the situation of their master basic theoretical knowledge and on the basis of the original material, and the psychological reality of desire is to get correct evaluation and not from the university teachers, or teachers to elaborate their point of view to hear the voice of reason. At this time, the university teacher's comment is particularly critical. The premise of university teacher's comments should be shown in the next section of their point of view, interaction and Discussion on students' enthusiasm spirit should give more encouragement and praise.

\section{Principles of small class interaction teaching}

\section{1)The elite of college teachers}

The subject of higher education is a college teacher. In order to implement the elite education, a teacher who teaches the "elite" teachers must be established, teacher students must be convinced of the selection of experts and professors, and engaged in educational work well must be introduced to form education elite team. At the same time, universities should strengthen the training of other university teachers, focusing on the development of teaching potential and comprehensive quality of College teachers. Establish a dynamic adjustment mechanism, strict screening in the elite education of the university teachers, and constantly improve the educational elite team.

\section{2) Guide the students' specialty, personality correctly}

The work of teaching, teachers should pay much attention to guide students to self-discovery, self-perfection and individualized. It is necessary to point out that the elite education is not equal to the all-round education, but at an extremely prominent or of a professional or skilled and interested students, students are full of personality. Personality is the performance of self-consciousness; personality is the charm and source of innovation. The teacher recognized and respected the students' personality, respect for students' hobbies, interests, in order to follow the objective law of personality development.

\section{3) Multiple evaluation}

University teachers should continue to improve the strategy under the new curriculum idea, and the ability to control the classroom and adaptability. The students often respond to university teacher's imagination, many ideas and understanding one another, as university teachers must make good use of this platform class, rushed forward. The students in class and in the future the incentive to actively carry out creative thinking is an inestimable role. Universities should regularly invite high level experts outside the school, for small class students to open humanities, science and technology seminars.

\section{Misunderstanding OF UniVERsity "Elite EDUCATION"}

On the surface, the mass education is democratic and equal, and the elite education is noble. In fact, in the stage of higher education popularization, there is a certain amount of elite education. Mass education and elite education are two different development directions. They are the components of the strategy of developing the country through science and education. In promoting the elite education in the University, the local colleges and universities are worth our thinking and alert.

\section{A. Misunderstanding of the concept of Higher Education}

With the enhancement of people's democratic consciousness, people have extended the democratic consciousness to the field of higher education. Such as higher education democratization, higher education fair and so on. However, this kind of fair in a certain degree is the ideal. The ideal of the super reality will inevitably cause considerable pressure on the University of the implementation of elite education, and even inhibit the progress of college orientation.

\section{B. The misunderstanding of higher education management}

For a long time, because of the influence of planned economy, the management system has been adopted in the field of higher education in our country. The government has always been the main subject of management and restriction of colleges and universities. The government pays attention to the process management of the University and the non-target management. This kind of management system with mandatory administrative intervention, which is lack of service function, will inevitably lead to the behavior of the University. The key colleges and universities which undertake the important task of the elite education should carry out the instruction of the education administration department, and undertake the task of mass education. The quality of education is seriously threatened, and then the elite education and mass education.

\section{The misunderstanding of higher education funds}

In order to get more help and policy on the care of the policy, the blind positioning of ordinary colleges and universities to try to squeeze into the ranks of key universities. Therefore, the problem of education funding is an important factor in the devaluation of the elite education.

\section{CONCLUSION}

To sum up, the elite education in universities is an important measure to strengthen the quality advantage, innovation teaching process and personnel training mode of 
talents training. It is a long-term, comprehensive and systematic project to explore a university teaching mode which is suitable to the elite education. We must make full thought preparation, overcome heavy resistance, and constantly sum up experience and lessons, and constantly strive to explore practice.

\section{REFERENCES}

[1] T. Martin. "Problems in the transition from elite to mass higher education,” Fhei.Beijing, vol. A51, pp. 3-8, Feb 1999.
[2] L.L.Dan. "Thinking on the function orientation of Chinese colleges and universities in the popularization stage,” Hem.Beijing, vol. A112, pp. 85-87, Feb 2002.

[3] F.J.Zhu. "Enlightenment of foreign military in-service training to reform our military occupation education,” J.Her.Beijing, vol. A34, pp. 66-69, Mar 2011.

[4] M.Zeng. "The characteristics and Enlightenment of foreign education reform development” J.Rhee.Beijing, vol. A31, pp. 57-60, Mar 2001.

[5] X.Li. "Comparison and analysis of evaluation index system of network course” J.Hue.Hebei, vol. A57, pp. 17-19,Jan 2008.

[6] Q.G.Hu. "Comprehensive evaluation of teaching quality in Colleges and Universities Based on group decision AHP” J.Hue.Hebei, vol. A58, pp. 55-57,Feb 2008. 